\title{
A Conceptual Framework for Analyzing the Use of Context in Groupware
}

\author{
Márcio G.P. Rosa ${ }^{1}$, Marcos R.S. Borges ${ }^{2}$, and Flavia M. Santoro ${ }^{2}$ \\ ${ }^{1}$ Departamento de Ciências da Computação/UFRJ \\ Caixa Postal 2324, Rio de Janeiro, 20001-970, RJ, Brasil \\ marciorosa@frb.br \\ ${ }^{2}$ Departamento de Ciências da Computação and NCE/UFRJ \\ Caixa Postal 2324, Rio de Janeiro, 20001-970, RJ, Brasil \\ \{mborges, flaviams\}@nce.ufrj.br
}

\begin{abstract}
This article presents a conceptual framework for the identification and classification of contextual elements included in groupware applications. Contextual elements store information that helps group members to characterize and to understand the interaction and its associate information. The conceptual framework can be used not only to guide the development of new groupware applications but also to analyze existing groupware. We illustrate the use of the framework in the analysis of three groupware tools.
\end{abstract}

\section{Introduction}

The groupware support to cooperative groups aims at generating better results than when team members work together without computational support. Fast communication channels for distributed teams and computerized memory are only two examples of where technology may enhance the group's interaction. However, technology also gives rise to problems, which are hard to overcome, making existing complex tasks even harder to accomplish.

One of the most important aspects in supporting cooperation is the context upon which interaction occurs among group members. Perhaps because in face to face interactions this aspect is almost taken for granted, many groupware tools have almost completely neglected the presentation of contextual information. Another reason may be due to the complexity of dealing with many kinds of context. Whichever is the case, however, the absence of support to contextual elements may reduce the value of the groupware and in some cases jeopardize its benefits.

Contextual elements can be about group members, the group itself, the scheduled and the completed tasks, the interaction that led to the concluded task and about the environment where the interaction took place. This information helps group members to know each other and be aware of their goals and the issues that influence them. With this information at hand, the group should be able to increase their level of awareness and cooperation.

This paper addresses the identification and the representation of contextual elements aimed at increasing the level of cooperation among group members. By explicitly defining contextual elements, we believe we can help groupware designers in 
including these elements in their systems. Another possibility is to include them as components in groupware toolkits, as proposed by David and Borges [8].

The need for the framework is justified because groupware designers do not usually provide contextual information. When analyzing some groupware systems we can notice that contextual information is neither explicitly dealt with nor, when present, well thought of. By analyzing the groupware system by using the framework we can show what may be missing in order to create a more complete tool.

We believe this framework proposal is a first step towards the building of a library of contextual elements, which can be used by groupware designers in building their applications.

To present our framework we first present a review of the main concepts behind context and groupware. Next we describe the proposed framework that consists of five types of context related to the group's interactions. We then apply the framework to identify the contextual elements present in three sample groupware applications. Finally, we conclude the paper with a discussion of the utility of the framework and the next steps of our work.

\section{Context and Groupware}

The issue of context has been an important area of research in recent years, although, there is no consensus as yet about what context really means, what its implications are and how it can be generalized [15]. Several domains have already elaborated their own working definition of context. In a human-machine interaction, a context is a set of information that could be used to define and interpret a situation in which interact agents [4]. In the context-aware applications community, the context consists of a set of information for characterizing the situation, which interact humans, applications and the immediate environment [9]. In artificial intelligence, the context does not intervene directly in problem solving but constrains it [5].

When we use the term context we should always refer it to something. There is no definition of context out of a context [4]. We can reference the context of a dissertation, a computer science course, a football game, etc. In this article, for example, the context of our work is groupware systems and applications.

Brézillon and Pomerol [6] proposed a classification for differentiating the contextual elements related to task performing. The set of contextual elements that are relevant to the task realization is called contextual knowledge. The knowledge that is shared by all people involved but is not used to perform a task is called external knowledge. During the execution of a task, a portion of the contextual knowledge is actually employed. This portion is called proceduralized context (Figure 1).

In the area of CSCW Araújo, Dias and Borges proposed a conceptual framework for the understanding of group support in collaborative projects [1]. Gutwin, Stark and Greenberg developed a framework for the categorization of awareness in cooperative learning [13]. Groupware usability in shared workspaces was the theme of a conceptual framework developed by Gutwin and Greenberg [12].

Other relevant work in the CSCW area is The Denver Model for Groupware Design, a nested collection of models describing the generic elements of any groupwareapplication. The first model consists of three sub models describing three aspects of 


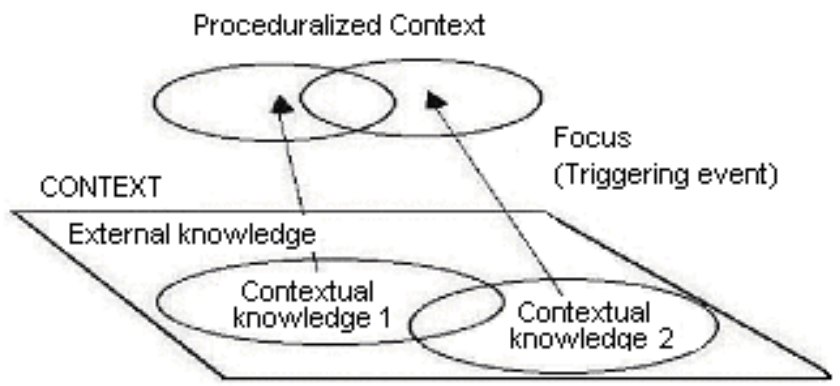

Fig.1. Three types of context

constructing and reviewing groupware applications: requirements, design and technology. According to the design's sub model, groupware applications can be characterized as five categories related to: people, artifacts, tasks and activities, interactive situations and social protocols (Figure 2) [18].

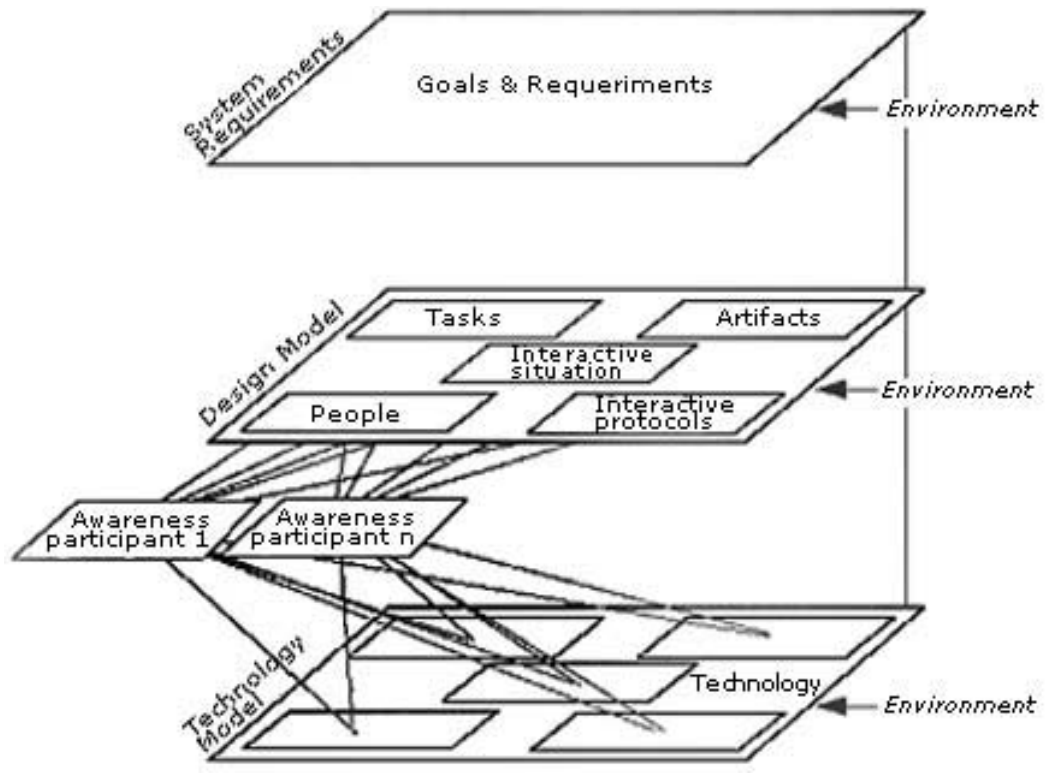

Fig. 2. The Denver Model for Groupware Design

In real life a context is a complex description of shared knowledge about physical, social, historical, or other circumstances within which an action or an event occurs. In order to fully understand many actions or events, it is necessary to have access to relevant contextual information [2]. A common drawback of many groupware tools is the lack of support to contextual information, making the cooperation hard to achieve.

When people work cooperatively as a team, the knowledge about the contextual elements related to the interactions is very relevant to achieving a high level of coop- 
eration. The context of the group is not simply the union of all individual contexts. It consists of information about the group, such as its composition, social protocols, goals, strategies, etc. Another important aspect is the proceduralization of the context by the group. Again, this proceduralization should occur in addition to the individual process [2].

\section{A Conceptual Framework}

According to Greenberg [11], a context is a dynamic construction that can be viewed in five dimensions: (1) time, (2) usage episodes, (3) social interactions, (4) internal goals, and (5) local influences. Although the contextual elements in some situations are very stable, understandable and predictable, there are some situations when this does not occur. Situations with apparently the same context can differ from each other.

Several aspects of these situations can explain this case. Among them, we can select the previous experience of the group, the task's characteristics, and the social and the technical facets of the interactions. This diversity and unpredictability of the aspects are factors that have a negative influence on the identification and the representation of the contextual elements related to group interactions.

In order to reduce this impact, we propose the use of a conceptual framework aimed to identify and classify the contextual elements most common in groupware tools. Conceptual frames will represent this framework. The goal of the framework is to supply guidelines for research and development in the area of groupware and context [19].

Several proposals have been presented to classify context in particular domains. In the area of Intelligent Tutoring Systems (ITS), a framework for the classification of context has been divided into three groups: Interactional context, Environmental context and Objectival contexts [15]. In context-aware applications, the contextual information has been classified in four categories: identity, location, status (or activity) and time [9].

The conceptual framework proposed in this work considers the relevant elements for the analysis of the use of context in groupware applications. The contextual information is clustered in five main categories: (1) information about people and groups, (2) information about scheduled tasks, (3) information about the relationship between people and tasks, (4) information about the environment where the interaction takes place and (5) information about tasks and activities already concluded. The clusters were derived from the Denver Model [18], and in each cluster we try to identify the most relevant aspects of the interaction that influence the performing of group tasks.

In groupware synchronous environments, group members need to work simultaneously, but in asynchronous environments, there might be a time lag between the interactions. The needs of each type of environment are different, especially in relation to contextual information and the awareness required in each situation [16]. This justifies why in our framework we analyze each situation differently.

The framework proposed is a generic classification of contextual elements. It neither covers the particularities of a specific domain nor applies to a particular type of groupware. This generic framework can be seen as a starting point to a more specific 
classification of contextual elements in particular domains, where new contextual elements may be considered relevant.

In the next sub-sections we will describe seven types of contextual information grouped into the five categories. According to McCarthy [14], the size of the contextual dimension is infinite. Therefore, we will consider only the contextual elements, which we believe are the most relevant to task oriented groups; the contextual knowledge and the proceduralized context [3].

\subsection{Information about Individuals}

This is information about the individuals and the groups they belong to. The knowledge about the group's composition and its characteristics is important for the understanding of the potential ways the project or task will be developed. The knowledge about the characteristics of individuals and the group as a whole encourages the interaction and the cooperation [16].

The type of interaction - synchronous or asynchronous, does not influence this aspect of the context. In other words, the knowledge about individuals and groups is required independent of the timing aspect of the interaction. We divided this category into 2 types of context.

- Individual Context: Information about the individual who is a member of a group. It includes information about his/her abilities, interests, location, previous experience personal data and working hours, among others

- Group Context: Information about the characteristics of the team. The data is similar to the aforementioned, but related to the group. They include the composition of the team, its abilities and previous experience as a group, the organizational structure, e.g. the group's coordination, location, and working hours.

\subsection{Information about Scheduled Tasks}

This type of information tries to characterize the tasks to be performed by the group. The interaction may be synchronous or asynchronous, but it does not influence the contextual elements. In other words, independent of how the interaction occurs, the group members need to be acquainted with task characteristics. Task context is the name given to this context.

- Task Context: It stores the information about a task. Its goal is to identify tasks through its relevant characteristics. Among these characteristics, we can select the task name, its description and goals, the deadline, the predicted effort, the technology and other requirements and pre-conditions.

\subsection{Relationship between People and Tasks}

This type of information aims to represent the relationship between the members of the group and the scheduled tasks. Its goal is to relate the action of each group member and the interaction they are involved in, with the tasks and their corresponding 
activities, which are being developed. In the scope of this work, the interaction developed among group members begins with an execution plan and terminates when the task concludes, passing through a sequence of actions required for carrying out the plan. In some situations the interaction may be interrupted before the task is concluded. The reason for this premature termination is also part of the context and is relevant to the understanding of what justified the interruption.

For this group of information we also identified two types of contexts:

- Interaction Context: It consists of information that represents the actions, which took place during the task completing. It depends on the type of interaction. According to Pinheiro et al [16], when the interaction is synchronous, it is very important to be aware of the details of the activity at the time it occurs, while in asynchronous interactions it is more important to provide an overview of the activities instead of details, at least at the first level of awareness.

In the case of synchronous groupware, the interaction context includes detailed information about on-going tasks. This includes step-by-step details of activities performed towards the conclusion of the task.

- Planning Context: It consists of information about the project execution plan. This information can be generated at two different points. In the case of ad-hoc tasks, they appear as a result of the interaction, which decided about it. For the scheduled tasks, they are generated at the time of the plan, i.e., when the tasks are defined and the roles associated with them. They include rules, goals, deadline strategies, coordination activities, etc.

\subsection{Information about the Environment}

This type of information represents the aspects of the environment where the interaction takes place. It covers both the organizational issues and the technological environment. In other words, all information outside the project but within the organization that can affect the way the tasks are performed.

- Environment Context: It consists of information that characterizes the environment where the interaction takes place and that influences the task completion. The environment gives some additional indications to group members about how the interaction will occur. For example, the quality control patterns are part of this context. Strategy rules, policies, financial restrictions and institutional deadlines are other examples of this context.

\subsection{Information about Concluded Tasks}

This information tries to characterize the interactions that have already occurred. Its goal is to provide background information about the experiences learned either from the same group or similar tasks performed by other groups. It should include all contextual information about previous projects, which can be useful to future projects. 
Table 1. Conceptual framework for the analysis of context in groupware applications

\begin{tabular}{|c|c|c|c|c|}
\hline Information & Associated & Goals & \multicolumn{2}{|c|}{ Examples of contextual elements } \\
\hline \multirow{3}{*}{$\begin{array}{l}\text { Group } \\
\text { Members }\end{array}$} & Contexts & & & \\
\hline & $\begin{array}{l}\text { Individual } \\
\text { (Synchronous } \\
\text { \& Asynchro- } \\
\text { nous) }\end{array}$ & $\begin{array}{l}\text { To identify the partici- } \\
\text { pants through the repre- } \\
\text { sentation of their personal } \\
\text { data and profiles. }\end{array}$ & $\begin{array}{l}\text { - Name } \\
\text { - Qualifications } \\
\text { - Interests } \\
\text { - Academics } \\
\text { Education } \\
\end{array}$ & $\begin{array}{l}\text { - Previous experience } \\
\text { - Location } \\
\text { - Working hours } \\
\text { - Web page }\end{array}$ \\
\hline & $\begin{array}{c}\text { Group (Syn- } \\
\text { chronous \& } \\
\text { Asynchronous) }\end{array}$ & $\begin{array}{l}\text { To identify the group } \\
\text { through the representation } \\
\text { of its characteristics }\end{array}$ & $\begin{array}{l}\text { - Name } \\
\text { - Members } \\
\text { - Roles } \\
\text { - Abilities }\end{array}$ & $\begin{array}{l}\text { - Previous experience } \\
\text { - Organizational Structure } \\
\text { - Location } \\
\text { - Working hours }\end{array}$ \\
\hline $\begin{array}{l}\text { Scheduled } \\
\text { Tasks }\end{array}$ & $\begin{array}{l}\text { Task (Synchro- } \\
\text { nous \& Asyn- } \\
\text { chronous) }\end{array}$ & $\begin{array}{l}\text { To identify the tasks } \\
\text { through the representation } \\
\text { of its characteristics. }\end{array}$ & $\begin{array}{l}\text { - Name } \\
\text { - Description } \\
\text { - Goals } \\
\text { - Deadlines }\end{array}$ & $\begin{array}{l}\text { - Estimated effort } \\
\text { - Activities } \\
\text { - Restrictions } \\
\text { - Workflow }\end{array}$ \\
\hline \multirow{3}{*}{$\begin{array}{l}\text { Relationship } \\
\text { between } \\
\text { people and } \\
\text { tasks }\end{array}$} & $\begin{array}{c}\text { Interaction } \\
\text { (Synchronous) }\end{array}$ & $\begin{array}{l}\text { To represent in detail the } \\
\text { activities performed } \\
\text { during the task complet- } \\
\text { ing. }\end{array}$ & $\begin{array}{l}\text { - } \text { Group in-charge } \\
\text { - Messages } \\
\text { exchanged } \\
\text { - Presence } \\
\text { Awareness }\end{array}$ & $\begin{array}{l}\text { - Gesture awareness } \\
\text { - Concluded Activities } \\
\text { - Author } \\
\text { - Goal } \\
\text { - Report }\end{array}$ \\
\hline & $\begin{array}{c}\text { Interaction } \\
\text { (Asynchronous) }\end{array}$ & $\begin{array}{l}\text { To represent an overview } \\
\text { of the activities performed } \\
\text { during the task complet- } \\
\text { ing. }\end{array}$ & $\begin{array}{l}\text { - Group in-charge } \\
\text { - Artifacts gener- } \\
\text { ated } \\
\text { - Versions }\end{array}$ & $\begin{array}{l}\text { - Activities completed } \\
\text { - Author } \\
\text { - Goal } \\
\text { - Report } \\
\text { - Timestamp }\end{array}$ \\
\hline & $\begin{array}{c}\text { Planning } \\
\text { (Synchronous } \\
\text { \& Asynchro- } \\
\text { nous) }\end{array}$ & $\begin{array}{l}\text { To represent the Execu- } \\
\text { tion Plan of the task to be } \\
\text { performed }\end{array}$ & $\begin{array}{l}\text { - Roles in the } \\
\text { interaction } \\
\text { - Rules } \\
\text { - Aim }\end{array}$ & $\begin{array}{l}\text { - Responsibilities } \\
\text { - Strategies } \\
\text { - Coordination Procedures } \\
\text { - Working Plan }\end{array}$ \\
\hline Setting & $\begin{array}{c}\text { Environment } \\
\text { (Synchronous } \\
\text { \& Asynchro- } \\
\text { nous) }\end{array}$ & $\begin{array}{l}\text { To represent the environ- } \\
\text { ment where the interac- } \\
\text { tion occurs; i.e., charac- } \\
\text { teristics that influence } \\
\text { task execution. }\end{array}$ & $\begin{array}{l}\text { - } \text { Quality patterns } \\
\text { - Rules } \\
\text { - Policies } \\
\text { - Institutional } \\
\text { deadlines }\end{array}$ & $\begin{array}{l}\text { - Organizational structure } \\
\text { - Financial constraints } \\
\text { - Standard procedures } \\
\text { - Standard strategies }\end{array}$ \\
\hline $\begin{array}{l}\text { Completed } \\
\text { Tasks }\end{array}$ & $\begin{array}{l}\text { Historical } \\
\text { (Synchronous } \\
\text { \& Asynchro- } \\
\text { nous) }\end{array}$ & $\begin{array}{l}\text { To provide understanding } \\
\text { about tasks completed in } \\
\text { the past and their associ- } \\
\text { ated contexts. }\end{array}$ & $\begin{array}{l}\text { - Task Name } \\
\text { - Activities } \\
\text { - Author } \\
\text { - Goal } \\
\text { - Justification } \\
\text { - Date }\end{array}$ & $\begin{array}{l}\text { - Versions of the artifacts } \\
\text { - Contextual elements used } \\
\text { to carry out the task } \\
\text { - Working Plan } \\
\text { - Task Goals }\end{array}$ \\
\hline
\end{tabular}

At the end of a project all contextual information generated and used should be selected, clustered and stored for future retrieval. The type of interaction - synchronous or asynchronous - in this case part of the information is stored, but it does not influence the context itself. We called this set of information 'historical context'.

- Historical Context: It consists of information about projects and tasks already concluded. This information is important for the understanding of errors and successful approaches in previous projects to be used in current tasks. It can also be used out of the context of a project to provide insight into working practices and team cooperation.

The tool should not only store the information concerned with the current project but also provide support for the selected retrieval of past projects. The appropriate selection and the granularity of the information are key factors for the use of this context. Granularities, which are too coarse or too fine, may not provide the necessary aid for group members. 


\subsection{A Summary of the Framework}

After identifying the seven types of contexts we can group them in a framework table shown in Table 1. In this table we present a summary of each context and provide some examples of information that can influence the interactions in the group.

\section{Applying the Framework}

In order to provide the first test for the framework, we analyzed three groupware tools in relation to their treatment to contextual elements. The three tools selected were the BSCW - Basic Support for Cooperative Work [7], the FLE3 - Future Learning Environment [10], and the Quickplace 3 [17]. The result is reproduced in two tables. Table 2 lists the contextual elements identified in each tool. Table 3 describes how each tool would fit into the seven contexts of the framework. At the end of the section we discuss the application of the framework.

BSCW. The BSCW Shared Workspace System is a groupware application, developed at the GMD - German National Research Center for Information Technology. The BSCW runs on the Web and supports both synchronous and asynchronous interactions among group members.

The system's central metaphor is the shared workspace. The workspace contains several types of objects, such as documents, pictures, discussion lists, tables, spreadsheets, and so forth. Group members asynchronously access the shared workspace to carry out their tasks. The support to synchronous interaction is provided by two mechanisms: a meeting support tool and a Java applet, called JMonitor.

FLE3. The FLE3 is a collaborative learning environment based on the Internet. It consists of three learning aid tools:

1. The WebTop can be used by learners and instructors to store and share several types of documents related to the object of study. The documents can be organized into folders associated to each course. The two other tools share these folders.

2. The Knowledge Building is a discussion forum where most of the group's knowledge is actually built. The messages exchanged during a discussion can be classified according to an attribute named "knowledge type", which identifies the type of knowledge assumed by its author for each message presented.

3. Jamming is a shared workspace for the cooperative building of multimedia artifacts (photos, audio, video, etc). The Jamming allows the preservation of an object's data by storing the versions generated during its lifetime.

Quickplace 3. The QuickPlace 3 is a groupware system based on the Web. The central metaphor is the shared workspace, similar to the BSCW. The workspace can store any type of document, such as spreadsheets, discussions, workflows, and so on. The Quickplace 3 allows the publication and the sharing of any type of information relevant to the collaborative project. Besides this basic functionality, the system supports group discussions, agenda, chats, event notification and the evolution of the documents stored in the workspace. 
Table 2. Contextual elements identifyed in each tool

\begin{tabular}{|c|c|c|c|c|c|c|c|c|}
\hline Contexts & $\begin{array}{c}\text { Examples of contextual } \\
\text { elements }\end{array}$ & B & $\mathrm{F}$ & $\mathrm{Q}$ & $\begin{array}{c}\text { Examples of contextual } \\
\text { elements }\end{array}$ & $\mathrm{B}$ & $\mathrm{F}$ & Q \\
\hline \multirow{5}{*}{$\begin{array}{l}\text { Individual } \\
\text { (Synchronous } \\
\text { \& Asynchro- } \\
\text { nous) }\end{array}$} & Name & Ok & $\overline{O k}$ & $\overline{O k}$ & Organization & $\mathrm{X}$ & $\overline{O k}$ & $\mathrm{X}$ \\
\hline & Abilities & $\mathrm{X}$ & $\mathrm{X}$ & $\mathrm{X}$ & Location & $\mathrm{X}$ & $\mathrm{X}$ & $\mathrm{X}$ \\
\hline & Interests & X & Ok & $\mathrm{X}$ & Working hours & $\mathrm{X}$ & $\mathrm{X}$ & $\mathrm{X}$ \\
\hline & Academic background & $x$ & $\mathrm{X}$ & $\mathrm{X}$ & Personal data & Ok & Ok & Ok \\
\hline & Experience & $\mathrm{X}$ & $\mathbf{O k}$ & $\mathrm{X}$ & Personal Web Page & Ok & Ok & $\mathrm{X}$ \\
\hline \multirow{5}{*}{$\begin{array}{l}\text { Group } \\
\text { (Synchronous } \\
\text { \& Asynchro- } \\
\text { nous) }\end{array}$} & Name & Ok & $\mathrm{X}$ & Ok & Experience & $\mathrm{X}$ & $\mathrm{X}$ & $\mathrm{X}$ \\
\hline & Components & Ok & $\mathrm{X}$ & Ok & Organizational structure & $\mathrm{X}$ & $\mathrm{X}$ & $\mathrm{X}$ \\
\hline & Roles & Ok & $\mathrm{X}$ & $\mathrm{X}$ & Location & $\mathrm{X}$ & $\mathrm{X}$ & $\mathrm{X}$ \\
\hline & Abilities & X & $\mathrm{X}$ & $\mathrm{X}$ & Working hours & $\mathrm{X}$ & $\mathrm{X}$ & $\mathrm{X}$ \\
\hline & Interests & $\mathrm{X}$ & $\mathrm{X}$ & $\mathrm{X}$ & & & & \\
\hline \multirow{5}{*}{$\begin{array}{l}\text { Task } \\
\text { (Synchronous } \\
\text { \& Asynchro- } \\
\text { nous) }\end{array}$} & Name & $\mathbf{O k}$ & $\mathrm{X}$ & $\mathbf{O k}$ & Estimated effort & $\mathrm{X}$ & $\bar{X}$ & $\mathrm{X}$ \\
\hline & Description & Ok & $X$ & Ok & $\begin{array}{l}\text { Actions to be per- } \\
\text { formed }\end{array}$ & $\mathrm{X}$ & $\mathrm{X}$ & $\mathrm{X}$ \\
\hline & Goal & X & $X$ & $\mathrm{X}$ & Restrictions & $\mathrm{X}$ & $\mathrm{X}$ & $\mathrm{X}$ \\
\hline & Deadline & X & $\mathrm{X}$ & $\mathrm{X}$ & Technology & $\mathrm{X}$ & $\mathrm{X}$ & $\mathrm{X}$ \\
\hline & Requirements & $\mathrm{X}$ & $\mathrm{X}$ & $\mathrm{X}$ & & & & \\
\hline \multirow{4}{*}{$\begin{array}{l}\text { Interaction } \\
\text { (Synchro- } \\
\text { nous) }\end{array}$} & Assigned group & Ok & $\mathrm{X}$ & Ok & $\begin{array}{l}\text { Actions to be per- } \\
\text { formed }\end{array}$ & $\overline{O k}$ & $\mathrm{X}$ & Ok \\
\hline & Presence Notion & Ok & $X$ & Ok & Author of each action & Ok & $\mathrm{X}$ & Ok \\
\hline & Messages exchanged & Ok & $\mathrm{X}$ & Ok & Goal of each action & $\mathrm{X}$ & $\mathrm{X}$ & $\mathrm{X}$ \\
\hline & Gestures & X & $\mathrm{X}$ & $\mathrm{X}$ & $\begin{array}{l}\text { Justification for the } \\
\text { action }\end{array}$ & $\mathrm{X}$ & $\mathrm{X}$ & $\mathrm{X}$ \\
\hline \multirow{4}{*}{$\begin{array}{l}\text { Interaction } \\
\text { (Asynchro- } \\
\text { nous) }\end{array}$} & Assigned group & Ok & Ok & $\mathbf{O k}$ & $\begin{array}{l}\text { Justification for the } \\
\text { action }\end{array}$ & $\mathrm{X}$ & $\mathrm{X}$ & $\mathrm{X}$ \\
\hline & Actions performed & Ok & $\mathbf{O k}$ & Ok & Artifact version & Ok & Ok & Ok \\
\hline & Author of each action & Ok & $\mathbf{O k}$ & Ok & Working period & Ok & Ok & Ok \\
\hline & Goal of each action & X & $\mathrm{X}$ & $\mathrm{X}$ & & & & \\
\hline \multirow{4}{*}{$\begin{array}{l}\text { Planning } \\
\text { (Synchronous } \\
\text { \& Asynchro- } \\
\text { nous) }\end{array}$} & Roles in the task & Ok & $\mathrm{X}$ & $\mathrm{X}$ & Strategies & $\mathrm{X}$ & $\mathrm{X}$ & $\mathrm{X}$ \\
\hline & Plan rules & $\mathrm{X}$ & $\mathrm{X}$ & $\mathrm{X}$ & $\begin{array}{l}\text { Coordination Proce- } \\
\text { dures }\end{array}$ & $\mathrm{X}$ & $\mathrm{X}$ & $\mathrm{X}$ \\
\hline & Goals & X & $\mathrm{X}$ & $\mathrm{X}$ & Implementation plan & Ok & $\mathrm{X}$ & Ok \\
\hline & Responsibilities & $\mathrm{X}$ & $\mathrm{X}$ & $\mathrm{X}$ & & & & \\
\hline \multirow{4}{*}{$\begin{array}{l}\text { Environment } \\
\text { (Synchronous } \\
\text { \& Asynchro- } \\
\text { nous) }\end{array}$} & Quality patterns & $\mathrm{X}$ & $\mathrm{X}$ & $\mathrm{X}$ & Institutional deadlines & $\mathrm{X}$ & $\mathrm{X}$ & $\mathrm{X}$ \\
\hline & Rules & $X$ & $\mathrm{X}$ & $\mathrm{X}$ & $\begin{array}{l}\text { Organizational struc- } \\
\text { tures }\end{array}$ & $\mathrm{X}$ & $\mathrm{X}$ & $\mathrm{X}$ \\
\hline & Procedures & $x$ & $\mathrm{X}$ & $\mathrm{X}$ & Policies & $\mathrm{X}$ & $\mathrm{X}$ & $\mathrm{X}$ \\
\hline & Strategies & $\mathrm{X}$ & $\mathrm{X}$ & $\mathrm{X}$ & Financial restrictions & $\mathrm{X}$ & $\mathrm{X}$ & $\mathrm{X}$ \\
\hline \multirow{5}{*}{$\begin{array}{l}\text { Historical } \\
\text { (Synchronous } \\
\text { \& Asynchro- } \\
\text { nous) }\end{array}$} & Task name & $\mathbf{O k}$ & $\mathbf{O k}$ & Ok & Author of each action & $\mathbf{O k}$ & Ok & $\mathbf{O k}$ \\
\hline & Task description & Ok & Ok & Ok & Goal of each action & $\mathrm{X}$ & $\mathrm{X}$ & $\mathrm{X}$ \\
\hline & Task Goals & $\mathrm{X}$ & $\mathrm{X}$ & $\mathrm{X}$ & $\begin{array}{l}\text { Justification for the } \\
\text { action }\end{array}$ & $\mathrm{X}$ & $\mathrm{X}$ & $\mathrm{X}$ \\
\hline & Implementation plan & Ok & $\mathrm{X}$ & Ok & Working period & Ok & Ok & Ok \\
\hline & Tasks performed & Ok & Ok & Ok & $\begin{array}{l}\text { Information about other } \\
\text { contexts used in the } \\
\text { task }\end{array}$ & Ok & Ok & Ok \\
\hline
\end{tabular}

\subsection{Using the Framework to Analyze the Tools}

Table 2 presents the evaluation of the contextual elements identified in each of these three tools using the framework. In Table 2 the $\mathbf{B}$ refers to BSBW, the $\mathbf{F}$ refers to FLE3 and the $\mathbf{Q}$ refers to Quickplace. The Ok means the groupware tool supplies this contextual information, while the $\mathbf{X}$ means the absence of context.

Figure 3 shows the way the BSCW deals with the team contextual information. Figure 4 reproduces the context interaction support in FLE3. The task context provided by 


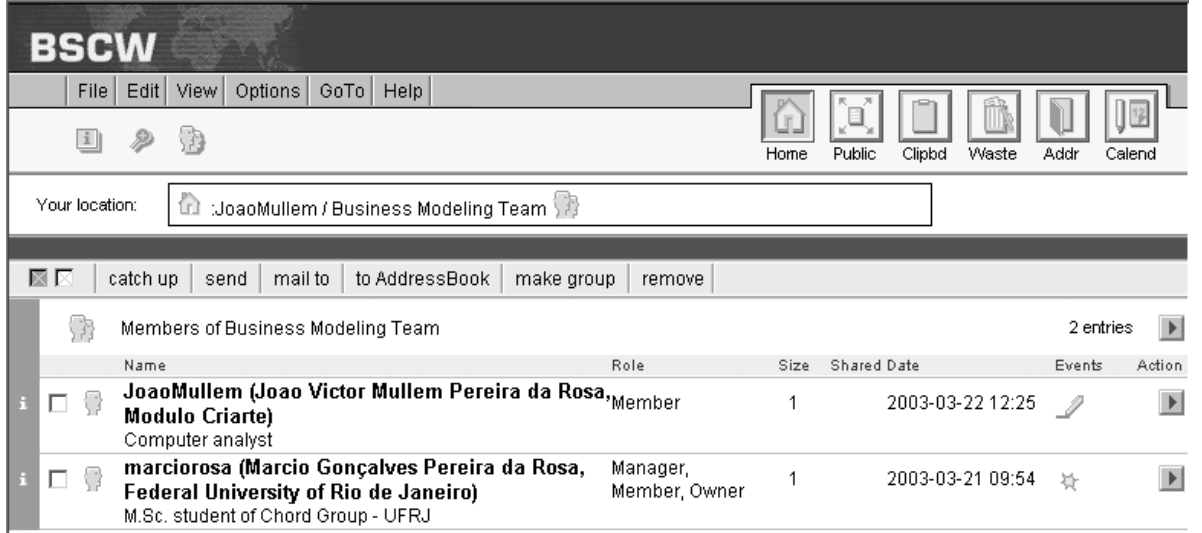

Fig. 3. Team context in BSCW

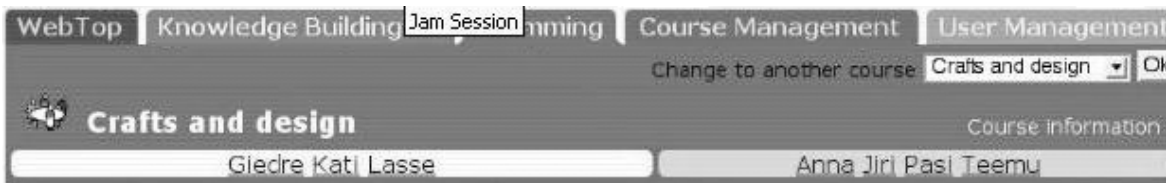

You are in: course Crafts and design/ jam session Designing a T-shirt Create link on WebTop

Description:

In this jam session we will design t-shirts for our great badminton team to wear during summer camp in Joensu.

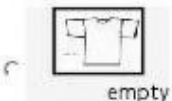

1 annotations

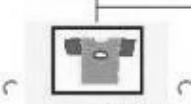

round Q annotations

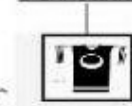

$$
\text { black }
$$

3 annotations

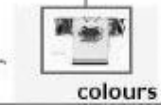

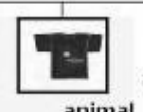

animal 0 annotations
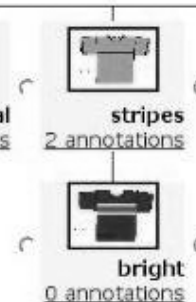

个 star

2 annotations

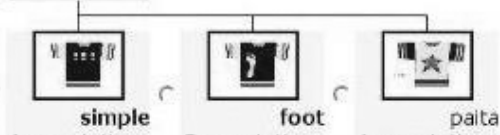

\section{.}

\section{.}

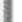
. 


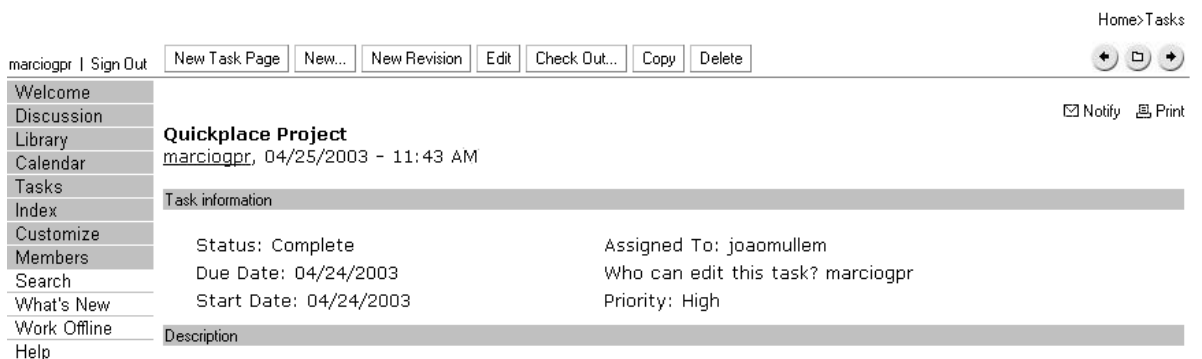

QuickPlace is a self-service Web tool for team collaboration. QuickPlace allows you to publish, share, and track all information relevant to a project with other members of your team. Teams can use QuickPlace to store resources (such as files, thoughts, and schedules) related to a project in a common place, where everyone can find and respond to the latest information

Fig. 5. Task context in Quickplace 3

\begin{tabular}{|c|c|c|c|c|c|c|}
\hline \multirow[b]{2}{*}{ marciogpr I Sign Out } & & & & & \multirow{2}{*}{\multicolumn{2}{|c|}{$\begin{array}{c}\text { Home }>\text { Tasks } \\
+\rightarrow\end{array}$}} \\
\hline & \multirow[t]{2}{*}{ New Task Page } & New... & Cleanup & Folder Options & & \\
\hline Welcome & \multirow{3}{*}{\multicolumn{4}{|c|}{ Tasks }} & \multirow{3}{*}{\multicolumn{2}{|c|}{$\square$ Notify 且Print }} \\
\hline Discussion & & & & & & \\
\hline Library & & & & & & \\
\hline Calendar & \multicolumn{4}{|l|}{ Daus I Weeks } & = & All Tasks | Milestones 1 To Do \\
\hline Tasks & \multirow{2}{*}{\multicolumn{3}{|c|}{ Task }} & & & May \\
\hline Index & & & & Assigned To & $\begin{array}{llllllllllllll}18 & 19 & 20 & 21 & 22 & 23 & 24 & 25 & 26 & 27 & 28 & 29 & 30\end{array}$ & 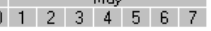 \\
\hline Customize & \multirow{5}{*}{$\begin{array}{l}\text { ! Framework } \\
\checkmark \text { Criarte Proj } \\
\checkmark \text { CSCW Proje } \\
\checkmark \text { Groupware }\end{array}$} & Project & & Students Group & & \\
\hline Members & & ct & & joaomullem & 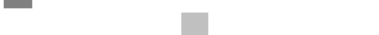 & \\
\hline Search & & & & Students Group & 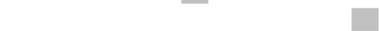 & \\
\hline What's New & & Contex & tProject & renato & & \\
\hline $\begin{array}{l}\text { Work Offline } \\
\text { Help }\end{array}$ & & & & & & \\
\hline
\end{tabular}

Fig. 6. Planning context in Quickplace 3

Quickplace is reproduced in Figure 5. Figure 6 illustrates the planning of activities also in Quickplace 3.

Based on the contextual elements identified in the tools we can then use the framework to provide a simple comparison of how the three tools deal with contextual information. This comparison is provided in Table 3.

\subsection{Discussion}

We can conclude at this point that the framework achieved its main objective, i.e., to be a first step towards the understanding of how contextual information is represented in groupware tools. We noticed a close relationship between the framework classification and the treatment given to contextual information by groupware tools.

In the application of the framework we identified some contextual elements in which specificity did not fit into our classification. An interesting example is the "type of knowledge" information in FLE3, a contextual element relevant to cooperative learning domains. In these cases, it is important to check if it corresponds to a more generic class in the framework, which was the interaction context. 
Table 3. Conditions to deal with contextual information

\begin{tabular}{|c|c|c|c|}
\hline Contexts & BSCW & FLE3 & Quickplace \\
\hline $\begin{array}{l}\text { Individual } \\
\text { (Sync \& Async) }\end{array}$ & $\begin{array}{l}\text { Very comprehensive about } \\
\text { the identification, but it does } \\
\text { not characterize him/her. }\end{array}$ & $\begin{array}{l}\text { Very comprehensive. It pro- } \\
\text { vides information about his/her } \\
\text { experience and its role. }\end{array}$ & $\begin{array}{l}\text { Little information about the } \\
\text { individual. It is not possible to } \\
\text { characterize him/her. }\end{array}$ \\
\hline $\begin{array}{l}\text { Group } \\
\text { (Sync \& Async) }\end{array}$ & $\begin{array}{l}\text { It adopts the team's concept, } \\
\text { but it does not describe the } \\
\text { group's characteristics. }\end{array}$ & $\begin{array}{l}\text { There is no group concept } \\
\text { implemented. }\end{array}$ & $\begin{array}{l}\text { It adopts the team's concept, } \\
\text { but it does not describe the } \\
\text { group's characteristics. }\end{array}$ \\
\hline $\begin{array}{l}\text { Task } \\
\text { (Sync \& Async) }\end{array}$ & $\begin{array}{l}\text { It defines task explicitly. It } \\
\text { allows the definition of } \\
\text { tasks, but it does not provide } \\
\text { additional details. }\end{array}$ & $\begin{array}{l}\text { It does not define task explic- } \\
\text { itly. The task definition is done } \\
\text { without system support. }\end{array}$ & $\begin{array}{l}\text { It defines task explicitly. It } \\
\text { allows the definition of tasks, } \\
\text { but it does not provide } \\
\text { additional details. }\end{array}$ \\
\hline $\begin{array}{l}\text { Interaction } \\
\text { (Synchronous) }\end{array}$ & $\begin{array}{l}\text { It supports only message } \\
\text { exchange. It associates } \\
\text { messages with their authors. } \\
\text { It provides the notion of } \\
\text { presence. It does not support } \\
\text { the definition of goals and } \\
\text { their justifications. }\end{array}$ & $\begin{array}{l}\text { It does not support synchronous } \\
\text { interaction. }\end{array}$ & $\begin{array}{l}\text { It supports only message } \\
\text { exchange. It associates } \\
\text { messages to its authors. It } \\
\text { provides the notion of pres- } \\
\text { ence. It does not support the } \\
\text { definition of goals and their } \\
\text { justifications. }\end{array}$ \\
\hline $\begin{array}{l}\text { Interaction } \\
\text { (Asynchronous) }\end{array}$ & $\begin{array}{l}\text { It identifies the tasks in } \\
\text { operation listing their } \\
\text { authors and dates. It does } \\
\text { not support the definition of } \\
\text { goals and justifications. }\end{array}$ & $\begin{array}{l}\text { It identifies the tasks in opera- } \\
\text { tion listing their authors and } \\
\text { dates. It does not support the } \\
\text { definition of goals and justifi- } \\
\text { cations. }\end{array}$ & $\begin{array}{l}\text { It identifies the tasks in } \\
\text { operation listing their authors } \\
\text { and dates. It does not support } \\
\text { the definition of goals and } \\
\text { justifications. }\end{array}$ \\
\hline $\begin{array}{l}\text { Planning } \\
\text { (Sync \& Async) }\end{array}$ & $\begin{array}{l}\text { It is represented through a } \\
\text { calendaring function that } \\
\text { stores part of the execution } \\
\text { plan and the role of each } \\
\text { member in the plan. }\end{array}$ & $\begin{array}{l}\text { There is no support to planning } \\
\text { context. }\end{array}$ & $\begin{array}{l}\text { It is represented through a } \\
\text { calendaring function that } \\
\text { stores part of the execution } \\
\text { plan. }\end{array}$ \\
\hline $\begin{array}{l}\text { Environment } \\
\text { (Sync \& Async) }\end{array}$ & $\begin{array}{l}\text { The application does not } \\
\text { support the representation of } \\
\text { information about the } \\
\text { environment supported by } \\
\text { the application. }\end{array}$ & $\begin{array}{l}\text { The application does not } \\
\text { support the representation of } \\
\text { information about the environ- } \\
\text { ment supported by the applica- } \\
\text { tion. }\end{array}$ & $\begin{array}{l}\text { The application does not } \\
\text { support the representation of } \\
\text { information about the envi- } \\
\text { ronment supported by the } \\
\text { application. }\end{array}$ \\
\hline $\begin{array}{l}\text { History } \\
\text { (Sync \& Async) }\end{array}$ & $\begin{array}{l}\text { All relevant information } \\
\text { about past tasks are stored } \\
\text { and a simple retrieval } \\
\text { mechanism is provided. }\end{array}$ & $\begin{array}{l}\text { All relevant information about } \\
\text { past tasks are stored and a } \\
\text { simple retrieval mechanism is } \\
\text { provided. }\end{array}$ & $\begin{array}{l}\text { All relevant information about } \\
\text { past tasks are stored and a } \\
\text { simple retrieval mechanism is } \\
\text { provided. }\end{array}$ \\
\hline
\end{tabular}

On the other hand, some contextual elements may not be relevant to certain application domains. Its absence in the groupware tool does not represent a negative aspect. For example, the organizational structure may not be relevant to CSCL applications. Therefore, when applying the framework we should take into consideration the aim of each application.

An important aspect observed in our study is that not all contextual elements can be embedded in a groupware system. However, this fact doesn't mean that they are not implemented into the work practices of the team. The group, in some cases, can implement these elements by other means.

The analysis of the groupware tools using the framework showed they have similar characteristics in relation to contextual information. Other conclusions worth mentioning are:

1. All three groupware partially cover the individual, group, task and interaction contexts;

2. The environmental context is not addressed by any of these tools, indicating that this type of context is not calling the attention of groupware designers; 
3. The contextual elements available in all three tools identify the cooperative actions, but they are not able to answer why certain action was carried out. In other words, there is no concern for the justification of actions;

4. In the three tools there is no separation between the historical and the other contexts. All contexts are stored, but there is not a clear division between contexts, which are current and those, which have become historical.

\section{Conclusions}

This article presented a framework for the classification of the various types of context, which comprises the interaction among group members supported by a groupware tool. The framework classified the context, which embodies the interactions in a groupware application into five main categories: (1) information about the group and its members - individual and team contexts; (2) information about the scheduled tasks - task context; (3) information about the relationship between group members and tasks - interaction context and planning context; (4) information about completed tasks - historical context; and (5) information about the environment where the tasks are performed - environment context.

For each type of context, we described its definition and some examples of information that is normally associated with this context. We also listed some applications, which already represent this context in some way. Then, we applied the framework in the identification of contextual elements present in the three groupware tools.

The use of the framework for analyzing current groupware applications confirmed what we expected; that few contextual elements are supported by these tools. Although, some sort of support is always provided, they are seldom treated as an important aspect of the groupware tool. We firmly believe there is a clear need for explicit support of context in groupware tools.

The framework is considered as the first step towards offering assistance to groupware designers wanting to include contextual elements in their tools. The framework needs to be further evaluated by applying two approaches. Firstly, we need to test its comprehensiveness, that is, to check if the framework covers all contextual elements relevant to groupware applications. Secondly, we would like to verify the correlation between each contextual element and the change in the level of cooperation among group members who make use of the tool.

Acknowledgement. Márcio G.P. Rosa is sponsored by NCE (Master Thesis Scholarship). Flávia Santoro is sponsored by FAPERJ (process \#E-26/152.116/2001).

\section{References}

1. Araujo, R.M., Dias, M.S., Borges, M.R.S., "A Framework for the Classification of Computer-Supported Collaborative Design Approaches", Third CYTED-RITOS International Workshop on Groupware, pp. 91-100, El Escorial, Spain, September 1997

2. Borges, M.R.S., Brézillon, P., Pino, J. A. and Pomerol, J.-Ch., "Context and Awareness in Group Work", Article submitted for publication 
3. Brézillon, P. "Individual and team contexts in a design process". Proceedings of the 36th Hawaii International Conference on Systems Sciences, HICSS-36, Track "Collaboration Systems and Technology", R.H. Sprague (Ed.), IEEE, Los Alamitos, January 2003, In CD-ROM

4. Brézillon P. "Making context explicit in communicating objects". In Communicating Objects, C. Kintzig, G. Poulain, G. Privat, P.-N. Favennec (Eds.), Hermes Science Editions, Lavoisier, 2002

5. Brézillon P., "Context in problem solving: A survey". The Knowledge Engineering Review, vol. $14, \mathrm{n}^{\circ} 1,1999$, pp. 1-34

6. Brézillon P. e Pomerol J.-Ch. "Contextual knowledge sharing and cooperation in intelligent assistant systems". Le Travail Humain, 62 (3), PUF, Paris, 1999, pp.223-246

7. http://bscw.gmd.de/

8. David, J.M.N. \& Borges, M.R.S., "Supporting Context-Awareness in Web-based Groupware Development", Article submitted for publication, 2003

9. Dey, A.K., Salber, D. Abowd, G.D. "A Conceptual Framework and a Toolkit for Supporting the Rapid Prototyping of Context-Aware Applications", anchor article of a special issue on Context-Aware Computing, Human-Computer Interaction (HCI) Journal, Vol. 16(2-4), 2001, pp. 97-166

10. http://fle3.uiah.fi/

11. Greenberg, S., "Context as a Dynamic Construct". Human-Computer Interaction, 16 (2-4), Lawrence Erlbaum Associates Inc., 2001, pp. 257-268

12. Gutwin, C. e Greenberg, S., "The Mechanics of Collaboration: Developing Low Cost Usability Evaluation Methods for Shared Workspaces". IEEE 9th International Workshop on Enabling Technologies: Infrastructure for Collaborative Enterprises (WET-ICE'00). June 14-16, held at NIST, Gaithersburg, MD USA

13. Gutwin,. C., Stark, G. e Greenberg, S. "Support for Workspace Awareness in Educational Groupware", CSCL '95 Proceedings 1 September 1995

14. McCarthy, J., "Notes on formalizing context", Proceedings of the $13^{\text {th }}$ IJCAI, 1993, Vol. 1 , pp 555-560

15. Patel A, Russell D, Kinshuk, Oppermann R and Rashev R (1998) "An initial framework of contexts for designing usable intelligent tutoring systems", Information Services and Use, 18 (1,2), IOS Press, Amsterdam, 1998, pp. 65-76

16. Pinheiro, M.K., Lima, J.V., Borges, M.R.S.,"Awareness em Sistemas de Groupware", In Proc. of the IDEAS 2001, San Jose, Costa Rica, April 2001, pp. 323-335

17. http: //lotus.com/products/qplace.nsf/homepage/\$first

18. Salvador, T., Scholtz, J., Larson, J. "The Denver Model for Groupware Design”, SIGCHI Bulletin Vol.28, No. 1, January 1996

19. Santoro, F.M., Borges, M.R.S., Santos, N. "Um framework para estudo de ambientes de suporte à aprendizagem cooperativa", Revista Brasileira de Informática na Educação, n. 04, April 1999, pp. 51-68 (in Portuguese) 